\title{
Determinants of private domestic investment in Palestine: time series analysis
}

\author{
Ibrahim M. Awad \\ Economics, College of Economics and Business, Al Quds University, \\ Jerusalem, Palestinian Authority \\ Ghada K. Al-Jerashi \\ College of Economics and Business, Al Quds University, \\ Jerusalem, Palestinian Authority, and \\ Zaid Ahmad Alabaddi \\ College of Business Administration and Economics, \\ Al-Hussein Bin Talal University, Ma'an, Jordan
}

\begin{abstract}
Purpose - This empirical paper aims to examine the impact of interest rate (IR) and political instability (POLINS) on Palestine's domestic private investment.

Design/methodology/approach - A set of econometric techniques of time series data are adopted to meet the study objectives. They include regression analysis, unit root tests, cointegration test, ARDL \& Bound tests, VAR test and Granger causality test.

Findings - The study's primary results complement the neoclassical approach, which states that the IR is negatively associated with domestic private investment. The empirical results reveal that there is no long-run relationship. Also, there is no causality between domestic investment and lending rates. Accordingly, these findings alert policymakers to draw a series of steps to minimize the IR at a minimum to stimulate investment for improved economic growth and development.

Practical implications - There is still no national currency in Palestine. The Palestinian Monetary Authority (PMA) is advised to set an appropriate ratio of the IR for the currencies-in-circulation in Palestine for boosting investment and economic development.

Originality/value - This paper provides new background information to both policymakers and researchers on the main determinants of investment in Palestine using econometric analysis. Accordingly, this critical issue is required to be examined in Palestine for stimulating investment.
\end{abstract}

Keywords Econometrics, Investment, Interest rate, Palestine, Times series

Paper type Research paper

\section{Research background}

In 1936, the Keynesian theory was developed by John Maynard Keynes to investigate the great depression. Especially, it is considered a demand-side theory, which focuses on changes in the economy in the short term. However, investment as one of the main components of the aggregate demand is worthy to be considered for stimulating economic growth, economic development, GDP, employment and prosperity.

(C) Ibrahim M. Awad, Ghada K. Al-Jerashi and Zaid Ahmad Alabaddi. Published in Journal of Business and Socio-economic Development. Published by Emerald Publishing Limited. This article is published under the Creative Commons Attribution (CC BY 4.0) licence. Anyone may reproduce, distribute, translate and create derivative works of this article (for both commercial and non-commercial purposes), subject to full attribution to the original publication and authors. The full terms of this licence may be seen at http://creativecommons.org/licences/by/4.0/legalcode

The authors thank the colleagues from Al-Quds University and internationally for their assistance and their significant comments that significantly improved the manuscript.

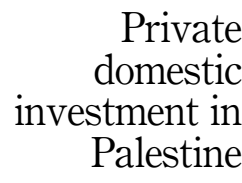

Received 2 April 2021

Revised 30 April 2021

4 May 2021

5 May 2021

Accepted 5 May 2021 
JBSED

1,1

In Palestine, there is an insignificant contribution of bank lending to GDP because banks exhibit apathy in lending to the economy's production sector due to the high level of risk involved (Awad and Karaki, 2019). The Palestinian government is advised to raise awareness campaigns to enhance the community's awareness about the necessity of adherence to laws and public interest regulations. Accordingly, the underground economy should be integrated with the formal economy instead of reducing it according to a clear plan to achieve that integration (Awad and Alazzeh, 2020).

However, this study addresses two main determinants of domestic private investment. The interest rate (IR) is the main factor that may affect private investment. IRs in Palestine are high compared with developing and developed. For instance, Israel, the USA and Japan have very low and close to zero IR policy. Moreover, the IR in Egypt and Jordan is significantly lower than the IR in Palestine.

In contrast, according to the Palestinian Monetary Authority (PMA) the average IR in Palestine between 2008 and 2017 was about $6.94 \%$. The political situation variable is also considered, which is likely to discourage businesses from undertaking investment projects. Previous studies also suggest that economic growth and political instability (POLINS) are strongly linked. The uncertainty associated with an unstable political environment may reduce investment or cause increases in the price level, which leads to a high level of inflation and, as a result, a lower national growth rate.

Given that, this empirical study tends to find out to what extent the IR and POLINS affect domestic private investment in Palestine from 2008 to 2017. This paper aims to examine the impact of IR and POLINS on Palestine's domestic private investment.

The study is organized as follows. The next section reviews some of the most important contributions in the literature to locate this paper's policy aims. Section 4 describes the methods employed to analyze the data. Section 5 presents the empirical findings of the paper and discussions these results. Finally, concluding remarks and policy implications are in Section 6.

\section{Theories of investment and interest rate}

\subsection{Classical theory}

According to this theory, supply creates demand. The act of producing goods generates an income equal to the value of the goods being produced. Agrawal (2004) finds that any unbalance in the price level, aggregate demand, or aggregate supply will eventually return the economy to an equilibrium state.

On the other hand, Classical economists believe that the IR will fall, causing investors to demand more of the available savings to supply funds from aggregate saving equal to the demand for funds by all investors (Athukorala, 2007). An increase in saving will lead to an increase in investment expenditure by reducing the IR, and the economy will always return to the natural level of real GDP (Thirlwall and Warman, 2007). Ohlin (1937) shows that the change in interest level is determined by the supply of and demand for credit. Robertson (1934) indicates that the natural rate of interest is the rate at which the new lending can be absorbed by industry per atom of time and the newly available savings for the atom of time are equal.

\subsection{Keynesian theory}

Hansen (1951) indicates that the Keynesian theory of interest like the classical theory. According to the Keynesian case, the demand and supply schedules cannot give the rate of interest unless we know the income level, while the demand and supply schedules for saving offer no solution until the income is known as figured out in the classical case. Pirayoff (2004) indicated that the price of IR is determined based on the market forces where the demand for 
and the supply of money are equal. Ohlin (1937) revealed that the difference between the Keynesian theory of interest and the Stockholm theory of saving and investment lies in the fact that Keynesian theory gives the quantity of cash a central place. On the other hand, the Stockholm theory states that the quantity of claims plays a key role and provides a direct link with saving, investment and the whole economic process.

\subsection{Neoclassical theory and its applicability to Palestine}

Neoclassical theory focuses on supply and demand as the driving forces behind the production, pricing and consumption of goods and services. Stiglitz (1968), (1987) is a contemporary economist who contradicts the approach's deregulation of IRs. He advocates government intervention as Keynes did to manage the market effectively. As one of the developing countries, the Palestinian economy is small and relatively open, with several large holding companies dominating specific sectors. It is mainly services-oriented with agriculture accounting for about $30 \%$ of GDP, industry about $8 \%$, construction about $12 \%$ and services accounting for the remaining $50 \%$. Private sector activity dominates the economy for about $85 \%$ of GDP. The main feature of the Palestinian economy is its heavy dependence on the Israeli economy (Dabour, 1998), (PCBS, 2017).

\section{Previous empirical research}

Nana (2016) tests for stationary using the ADF test and the ARDL estimation technique in the analysis. The results reveal that the higher real IR would increase private savings, which would also increase capital accumulation and private investment. Etim et al. (2018) acknowledge that the maximum lending rate has a positive effect on domestic private investment in the short and long runs and is significant in the short-run. The prime lending rate has a negative and insignificant impact on domestic private investment in both the long run and the short run. On the other hand, Mbaye (2012) shows that the lending IR negatively affects domestic investment in Kenya. Anthony and Joe (2015) tell that the increment in IRs, inflation rates and exchange rates lead to a decrease in investment.

Whereas the following studies agree with Keynesian and neoclassical approaches, Nelson (2018) finds that the increase in lending IRs would decrease domestic private investment, and the more stable a political environment is, the more increase in domestic private investment. Aftab et al. (2016) find that the IR is determined by the supply of loanable funds and demand for credit, supporting the neoclassical approach. Qahtani (2015) examines the effect of IR on the Saudi economy for the period of (2005-2013) multiregression model was estimated using the method of VAR in most sectors of the Saudi economy. The main result of his study is that IRs affect investment negatively. Jelilov (2016) finds the IR has a slight impact on growth, the growth can be improved by lowering the IR, to increase the investment level. The statistical analysis result reveals that a unit change in the investment will lead to growth.

Ojima and Fabian (2015) examine the impact of IR on investment in Nigeria. According to the relationship between the IR and investment, the results are negative in Egypt, positive in the countries with high-income levels, and no significant relation in the countries with medium and low levels. Abadi and Husain (2013) show a negative relationship between the real IR, economic reforms and money supply, whereas there is a positive relationship between the gross fixed capital formation and population. Mushtaq and Siddiqui (2016) reveal that people do not care about IRs in Islamic countries while saving. Still, growth in GDP per capita income seems to affect the saving decision positively. For non-Islamic economies, GDP per capita growth and IR both have a positive impact on saving. In investment, IR negatively affects GDP growth while GDP per capita positively affects both Islamic and non-Islamic countries.

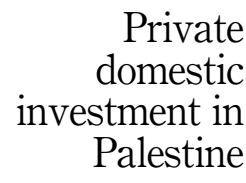


JBSED

1,1

Given these previous studies, there is a significant effect of IR on GDP growth. In contrast, some studies support the neoclassical approach to POLINS, which is the POLINS is one of the determinants of investment and economic growth that affect them negatively. For example, Radu (2015) shows that political determinants do not contribute directly to economic development.

Nazeer and Masih (2017) show that there are both long- and short-run relationships between POLINS, FDI and economic growth in Malaysia. Abdel Kader (2015) reveals that the effect of POLINS on economic growth is ambiguous in the case of Egypt. Najaf and Khakan (2016) acknowledge that political stability is crucial for expanding foreign direct investment.

\section{Methodology}

In the context of this empirical study, time series data were undertaken over the period: (from quarter 1/2008 to quarter 4/2017), the data were collected from the PMA and the Palestine Central Bureau of Statistics (PCBS) (PMA, 2012; and PCBS, 2017). To obtain a better scale to observe the scatterplot's data, we transformed the study variables to log so that the natural logarithm was considered in the study. Further, a set of econometric techniques of regression analysis, unit root tests, cointegration test, ARDL \& Bound tests, VAR test, Granger causality test and autocorrelation test were adopted to meet the study objectives.

This study is distinguished from other previous studies by using several econometric techniques, most of the previous studies that are mentioned above used at most four econometric techniques, this issue may rich this study in the econometric analysis.

\subsection{Regression analysis}

The regression model is developed, as shown in Eqn (1) shown below:

$$
\mathrm{INV}=\beta_{0}+\beta_{1} \mathrm{GDP}_{t}+\beta_{2} \mathrm{IR}_{t}+\beta_{3} \mathrm{POLINS}+\varepsilon_{t}
$$

where $\beta_{0}$ is constant and $\beta_{1}, \beta_{2}, \beta_{3}$ are the parameters of the econometric model, they describe the direction and the strength between variables, $\varepsilon$ is the residual.

The dependent variable is the domestic private investment (INV).

(1) Gross domestic product (GDP), this variable was chosen based on economic theory and previous research.

(2) IR, this variable was chosen based on economic theory and previous research.

(3) POLINS, a dummy variable $(0,1)$. When there is POLINS, it gets a value of 1 , when there is no POLINS, it gets a value of 0 .

Logarithmic transformations of variables were used to handle situations where a non-linear relationship exists between the independent and dependent variables. Stability tests were also conducted to examine the data stability to decide whether the model is suitable for policyrelated issues or not (Gujarati, 2020). The model considered stable if it satisfies the stability tests in the term of residuals and the squares.

\subsection{Unit-root tests}

4.2.1 Unit-root test. The unit root tests are used to determine whether the time series is stationary or nonstationary (Wooldridge, 2020). Suppose the data are nonstationary after the first difference. In that case, it means that the data follow a random walk, and according to the Gauss Markov theorem, the series will not have a finite variance. In this case, the ordinary least squares (OLS) will not yield consistent bound estimates. This study used a unit root test on the time series data, which is the augmented Dickey-Fuller test (ADF). The ADF tests the 
null hypothesis that a unit root is present in a time series sample, while the alternative hypothesis is usually stationary. The model runs, as shown in Eqn (2) below:

$$
\Delta Y_{t}=\beta_{0}+\beta_{1 t}+\beta_{2} X_{t-1}+\sum_{i=1}^{K-1} \beta_{i} \Delta X_{t-1}+\varepsilon_{t}
$$

HO. $\beta_{2}=0$ Data are nonstationary.

H1. $\beta_{2}<0$ Data are stationary.

\subsection{Lag length criteria}

Akaike information criterion (AIC) is used to fix the most appropriate lag of the quarterly study data so that lags are dropped until the last lag is statistically significant.

\subsection{Cointegration test}

Engle and Granger (1987) test was adopted in this study. He implemented ADF unit root tests on the residuals estimated for the cointegration regression. Given the possibility that the time series on the study variables are nonstationary and may be cointegrated.

\subsection{Autoregressive distributed-lag model (ARDL)}

This model is specified by Pesaran et al. (2001) for time series data. A regression equation is used to predict a dependent variable's current values based on both the current values of an explanatory variable and the lagged values of this explanatory variable. It uses a combination of endogenous and exogenous variables, unlike the VAR model, strictly for endogenous variables. Also, test for unit root to ascertain that no variable is integrated of order 2. ARDL can be specified if the variables are integrated into different orders. That is a model having a combination of variables with $\mathrm{I}(0)$ and $\mathrm{I}(1)$ integration order. There is no need to be integrated in the same order, and hence, there is no need for a pre-unit root test. In the ARDL approach, the variables set could be a combination of stationary, i.e. I(0), variables and integrated of I(1). The ARDL equation can be formulated as follows:

$$
Y_{t}=Y_{0 i}+\sum_{i=0}^{P} \sigma_{i} Y_{t-1}+\sum_{i=0}^{b} \beta_{i} X
$$

\subsection{Vector autoregressive model (VAR)}

The VAR approach, which was presented by Sims (1980), bypasses the need for structural modeling by treating every variable as endogenous in the model as a function of the lagged values of all endogenous variables in the system. VAR is commonly used for forecasting systems of inter-related time series and for analyzing the dynamic impact of random disturbances on a variable. The model of the study depends on three major variables, the variables that show significance in the regression model. They are the domestic investment, GDP and Shekel lending rate. The model specified as follows:

$$
\log \operatorname{inv}_{t}=a_{1}+\sum_{i=1}^{K} a_{1 i} \log \operatorname{inv}_{t-1}+\sum_{i=1}^{K} b_{1 i} \log g \operatorname{gp}_{t-1}+\sum_{i=1}^{K} d_{1 i} \log \mathrm{IR}_{t-1}+\varepsilon_{1 t}
$$


JBSED

1,1

76

$$
\begin{gathered}
\log \operatorname{gdp}_{t}=a_{2}+\sum_{i=1}^{K} a_{2 i} \log \operatorname{inv}_{t-1}+\sum_{i=1}^{K} b_{2 i} \log \operatorname{gdp} p_{t-1}+\sum_{i=1}^{K} d_{2 i} \log \operatorname{IR}_{t-1}+\varepsilon_{2 t} \\
\log \mathrm{IR}_{t}=a_{3}+\sum_{i=1}^{K} a_{3 i} \log \operatorname{inv}_{t-1}+\sum_{i=1}^{K} b_{3 i} \log g d p_{t-1}+\sum_{i=1}^{K} d_{3 i} \log \mathrm{IR}_{t-1}+\varepsilon_{3 t}
\end{gathered}
$$

where, $a_{i j}, b_{i j}$ and $d_{i j}$ are parameters to be estimated, the $\varepsilon$ 's are the stochastic error, often called impulses or shock elements. The dependent variable is a function of its lagged values and the lagged values of other variables in the model. $E$ 's are the stochastic error terms and called impulse or shock elements, and this helps to provide a clear distinction between correlation and causality as the impulse response function. The researcher logs the variables for direct estimation and interpretation of the coefficients as responsiveness or elasticity.

\subsection{Testing for residual autocorrelation}

Once a VAR model was developed, the next step is to determine if the selected model provides an adequate description of the data. In familiar regression models, it is performed by examining the residuals, which are differences between the actual observations and modelfitted values. In time series models, the autocorrelation of the residual values is used to determine the goodness-of-fit of the model. Autocorrelation of the residuals indicates that there is information that has not been counted for in the model. The Lagrange multiplier (LM) test is a standard tool for checking residual autocorrelation in VAR models. The null hypothesis is that there is no residual autocorrelation; the alternative is that residual autocorrelation exists.

\subsection{VAR and Granger causality}

VAR models describe the joint generation process of several variables over time so that they can be used for investigating relationships between the variables. Granger causality is one type of relationship between time series (Granger, 1969). The main idea of Granger causality can be stated if the prediction of one time series is improved by incorporating the knowledge of a second-time series. The latter is said to have a causal influence on the first. The null hypothesis for Granger Causality is that there is no explanatory power added by jointly considering the lagged $y$ and $x$ as predictors. The null hypothesis that $x$ does not cause $y$ rejection if coefficients for the lagged values of $x$ are significant; i.e. Granger called a variable $x$ causal for a variable $y$ if the lagged values of $x$ help improve forecasts of $y$. The VAR framework is flexible and provides an environment for implementing this type of analysis.

\subsection{Forecast error variance decomposition:}

A forecast error variance decomposition (FEVD) is another way to evaluate how variables affect each other using the VAR model. In a FEVD, forecast errors are considered for each equation in the fitted VAR model. Therefore, the fit VAR model is used to determine how much of each error realization comes from unexpected changes or forecast errors in the other variable.

\subsection{Impulse response function}

The impulse response function is usually made after any vector model of VAR, which is used to check the impact of the coefficient overtime. An impulse function traces the effect of a one 
standard deviation shock to one of the innovations (shock, impulse, residuals and error terms) on current and future values of endogenous variables. It helps compute the impulse response function, which tells us how one variable reacts to a shock in another variable over time.

\section{Empirical results}

\subsection{Regression analysis}

Table 1 shows the empirical results of the regression analysis. The dependent variable is the domestic private investment (INV). The independent variables include GDP, IR and POLINS as this variable was taken for regression analysis only. The result shows that the regression is not spurious since the $R$-squared of 0.87 is less than the Durbin-Watson, which is 1.07 . The domestic private investment is negatively associated with the IR; when the IR increases by $1 \%$, the domestic investment decreased by $19.4 \%$. This result is consistent with neoclassical and Keynesian theories, and it is compatible with other previous studies.

On the other hand, the domestic investment in this model is positively associated with POLINS; when the POLINS increased by $1 \%$, the domestic private investment increased by $40.99 \%$ (hence the political uncertainty is associated with the three attacked on the Gaza Strip, which interprets that the more object is damaged, the more is the need of expenditure, and so the more of domestic investment would take place. This result is consistent with the economic theory, which emphasizes that the more the government expenditure, the more the investment. The result implied that when there is an increase in GDP by $1 \%$, the domestic investment increases by $18.7 \%$.

The goodness-of-fit of adjusted $R$-squared for the model is $87 \%$, meaning that the independent variables are likely to explain the dependent one by this percentage. This result is fair enough to consider the model results in the analysis. Accordingly, The $F$-statistic is 0.0 , which implies that the $F$-statistic is statistically significant at a $1 \%$ level of significance.

\subsection{Unit root test}

The study undertakes the unit root test of the ADF test. The ADF tests the null hypothesis that a unit root is present in the study sample. The ADF test in Table 2 shows that not all variables achieved stationary at the same level. GDP, lending rate and POLINS were stationary at the second level. In contrast, the dependent variable domestic investment is stationary at the first level, so the study variables have a different order of integration. The results from the stationary test call for a long-run relationship.

\begin{tabular}{|c|c|c|c|c|}
\hline Variable & Coefficient & Std. Error & $t$-Statistic & Prob \\
\hline C & 78.29289 & 115.4503 & 0.678152 & 0.5020 \\
\hline GDP & 0.187173 & 0.031022 & 6.033662 & 0.0000 \\
\hline IR & -19.39280 & 5.541578 & -3.499508 & 0.0013 \\
\hline POLINS & 40.98877 & 12.90954 & 3.175076 & 0.0031 \\
\hline$R$-squared & 0.878607 & \multicolumn{2}{|c|}{ Mean dependent var } & 305.2818 \\
\hline Adjusted $R$-squared & 0.868491 & \multicolumn{2}{|c|}{ S.D. dependent var } & 102.3369 \\
\hline S.E. of regression & 37.11164 & \multicolumn{2}{|c|}{ Akaike info criterion } & 10.16038 \\
\hline Sum squared resid & 49581.87 & \multicolumn{2}{|c|}{ Schwarz criterion } & 10.32927 \\
\hline Log-likelihood & -199.2076 & \multicolumn{2}{|c|}{ Hannan-Quinn criter } & 10.22144 \\
\hline$F$-statistic & 86.85244 & \multicolumn{2}{|c|}{ Durbin-Watson stat } & 1.066607 \\
\hline
\end{tabular}

\section{Private domestic investment in \\ Palestine}

Prob ( F-statistic)

0.000000 
JBSED
1,1

78

\subsection{Lag length criteria}

It is essential to know the lag length, which is needed for the integrative test is to get the optimal lag length for integration. The results of Table 3 show that the optimal lag length is 1 , according to the selection criteria of Schwarz and Hannan Quinn. However, the Schwarz information criterion (SC) was used to determine the appropriate lag length to estimate the Johansen cointegration test (1).

\subsection{Cointegration tests}

The study proceeds Johansen cointegration test to determine if there is a long-run relationship between the dependent variable of INV and the independent variable of IR. Although a cointegration test needs to be done if the variables are integrated in the same order, the study will examine the results.

The results in Table 4 above show that the $p$-values are above $5 \%$, so that the null hypothesis is accepted and that there is no cointegration. Also, the values of T-statistics and the values of Max-Eigen statistic are less than the critical value; the null hypotheses of $r=0$ cannot be rejected because the trace statistic (4.910864) is less than the critical value (15.49471) this leads to accepting the null hypothesis where there is no cointegration between the domestic private investment and the lending IR. So the study goes with the ARDL test to examine the long-run of a different order of cointegration. ARDL can be tested to decide whether there is an integration or not of a variable of a different order; the dependent variable (INV) is stationary at the first difference, whereas the dependent variable of IR is stationary at the level, so they are stationary at different order. As a result, the ARDL test should be made.

\begin{tabular}{lcccccc}
\hline Variable & $T$-statistic & $\begin{array}{c}\text { Critical value } \\
1 \%\end{array}$ & $\begin{array}{c}\text { Critical value } \\
5 \%\end{array}$ & $\begin{array}{c}\text { Critical value } \\
10 \%\end{array}$ & $p$-value & $\begin{array}{c}\text { Order of } \\
\text { integration }\end{array}$ \\
\hline INV & -7.875663 & -2.627238 & -1.949856 & -1.611469 & 0.0000 & $\mathrm{I}(1)$ \\
Gdp & -4.760758 & -4.211868 & -3.529758 & -3.196411 & 0.0024 & $\mathrm{I}(0)$ \\
IR & -1.750190 & -2.627238 & -1.949856 & -1.611469 & 0.0760 & $\mathrm{I}(0)$ \\
POLINS & -2.589572 & -2.625606 & -1.949609 & -1.611593 & 0.0110 & $\mathrm{I}(0)$ \\
Note(s): Italic values refer 5\% level of significance & & & \\
\hline
\end{tabular}

Table 2 . augmented DickeyFuller test

\begin{tabular}{|c|c|c|c|c|c|c|}
\hline \multicolumn{7}{|c|}{$\begin{array}{l}\text { Endogenous variables: INV IR } \\
\text { Exogenous variables: } C\end{array}$} \\
\hline 0 & -218.5596 & NA & 8335.394 & 14.70397 & 14.79738 & 14.73385 \\
\hline 1 & -181.7448 & $66.26655^{*}$ & 936.2741* & 12.51632 & $12.79656^{*}$ & $12.60597^{*}$ \\
\hline 2 & -178.6081 & 5.227830 & 996.6484 & 12.57387 & 13.04094 & 12.72329 \\
\hline 3 & -175.5538 & 4.683323 & 1073.499 & 12.63692 & 13.29081 & 12.84610 \\
\hline 4 & -172.1409 & 4.777981 & 1139.547 & 12.67606 & 13.51678 & 12.94502 \\
\hline 5 & -164.9359 & 9.126314 & 951.6924 & 12.46240 & 13.48994 & 12.79112 \\
\hline 6 & -163.9760 & 1.087930 & 1226.541 & 12.66507 & 13.87944 & 13.05355 \\
\hline 7 & -161.8577 & 2.118290 & 1498.148 & 12.79051 & 14.19171 & 13.23877 \\
\hline 8 & -151.8103 & 8.707747 & 1113.574 & $12.38735^{*}$ & 13.97538 & 12.89538 \\
\hline 9 & -147.9178 & 2.854494 & 1304.121 & 12.39452 & 14.16937 & 12.96231 \\
\hline 10 & -145.0102 & 1.744573 & 1738.530 & 12.46735 & 14.42902 & 13.09490 \\
\hline
\end{tabular}

Note(s): * indicates lag order selected by the criterion; LR: sequential modified LR test statistic (each test at $5 \%$ level); FPE: Final prediction error; AIC: Akaike information criterion
VAR lag order selection criteria 
Series: INV IR

Lags interval (in first differences): 1 to 1

Unrestricted cointegration rank test (trace)

Hypothesized

No. of CE(s)

Eigenvalue

Trace statistic

\begin{tabular}{lcccc} 
No. of CE(s) & Eigenvalue & Trace statistic & 0.05 critical value & Prob.** \\
\hline None & 0.103630 & 4.910864 & 15.49471 & 0.8182 \\
At most 1 & 0.019636 & 0.753589 & 3.841466 & 0.3853
\end{tabular}

Palestine

Note(s): Trace test indicates no cointegration at the 0.05 level

*denotes rejection of the hypothesis at the 0.05 level

**MacKinnon et al. (1999) $p$-values

Unrestricted cointegration rank test (Maximum eigenvalue)

Hypothesized

\begin{tabular}{lcccc} 
No. of CE(s) & Eigenvalue & Max-Eigen statistic & 0.05 critical value & Prob.** \\
\hline None & 0.103630 & 4.157276 & 14.26460 & 0.8424 \\
At most 1 & 0.019636 & 0.753589 & 3.841466 & 0.3853
\end{tabular}

Note(s): Max-eigenvalue test indicates no cointegration at the 0.05 level

*denotes rejection of the hypothesis at the 0.05 level

Table 4.

**MacKinnon et al. (1999) p-values

\subsection{ARDL and bound test}

The study continues with the ARDL \& Bounds test to examine the effect of lending rate on domestic investment, and this test examines whether there is integration between these variables to decide if there is a long-run relationship or not. If the calculated $F$-statistic falls below the critical value for the lower bound $\mathrm{I}(0)$ bound, it could conclude that there is no cointegration, hence, no long-run relationship.

The obtained $F$-statistic of 1.797662 below the lower bound I $(0)$ at the $10 \%, 5 \%, 2.5 \%$ and $1 \%$ significance which indicates to accept the null hypotheses of no long-run relationships that means that there is no long-run relationship between the domestic investment and the lending rate. We will consider only short-run models since the variables show no evidence of a long-run relationship, as indicated by the bounds test results (see Table 5).

\subsection{VAR test}

The study used the VAR model to determine the relationship between the domestic investment (INV) and the IR, each column in Table 6 e-view reports the estimated coefficient, its standard error, and the $t$-statistic; for example, the coefficient for INV $(-1)$ in the IR

Null hypothesis: No long-run relationships exist

\begin{tabular}{lcr} 
Test statistic & Value & $K$ \\
\hline F-statistic & 1.797662 & 1 \\
\hline Critical value bounds & & I1 bound \\
Significance & I0 bound & 4.78 \\
\hline $10 \%$ & 4.04 & 5.73 \\
$5 \%$ & 4.94 & 6.68 \\
$2.5 \%$ & 5.77 & 7.84
\end{tabular}

Table 5. ARDL bounds test 


\begin{tabular}{|c|c|c|c|}
\hline $\begin{array}{l}\text { JBSED } \\
1,1\end{array}$ & \multicolumn{3}{|c|}{ Standard errors in () \& $t$-statistics in [ ] } \\
\hline \multirow[b]{5}{*}{80} & $\mathrm{D}(\mathrm{INV}(-1))$ & $-0.116808(0.17662)[-0.66135]$ & $-0.001387(0.00369)[-0.37644]$ \\
\hline & $\mathrm{D}(\operatorname{INV}(-2))$ & $-0.060343(0.17916)[-0.33680]$ & $0.000749(0.00374)[0.20033]$ \\
\hline & $\mathrm{D}(\mathrm{INV}(-3))$ & $-0.026893(0.17887)[-0.15035]$ & $0.003076(0.00373)[0.82431]$ \\
\hline & $\mathrm{D}(\mathrm{INV}(-4))$ & $-0.568803(0.17632)[-3.22598]$ & $0.004328(0.00368)[1.17644]$ \\
\hline & $\mathrm{D}(\mathrm{IR}(-1))$ & 14.17666 (9.94353) [1.42572] & $-0.475030(0.20748)[-2.28952]$ \\
\hline \multirow{14}{*}{$\begin{array}{l}\text { Table } 6 \text {. } \\
\text { Vector autoregression } \\
\text { estimates }\end{array}$} & $\mathrm{D}(\mathrm{IR}(-2))$ & $-2.112609(10.5910)[-0.19947]$ & $-0.178182(0.22099)[-0.80629]$ \\
\hline & $\mathrm{D}(\mathrm{IR}(-3))$ & $2.590014(10.9841)[0.23580]$ & $0.101422(0.22919)[0.44252]$ \\
\hline & $\mathrm{D}(\mathrm{IR}(-4))$ & $-3.372098(10.3648)[-0.32534]$ & $0.172006(0.21627)[0.79533]$ \\
\hline & $C$ & $13.73491(7.23100)[1.89945]$ & $-0.228269(0.15088)[-1.51291]$ \\
\hline & $R$-squared & 0.403543 & 0.219570 \\
\hline & Adj. $R$-squared & 0.220018 & -0.020563 \\
\hline & Sum sq. resids & 33334.88 & 14.51341 \\
\hline & S.E. equation & 35.80657 & 0.747133 \\
\hline & $F$-statistic & 2.198842 & 0.914368 \\
\hline & Log likelihood & -169.6956 & -34.25804 \\
\hline & Akaike AIC & 10.21117 & 2.471888 \\
\hline & Schwarz SC & 10.61112 & 2.871835 \\
\hline & Mean dependent & 7.153714 & -0.140857 \\
\hline & S.D. dependent & 40.54342 & 0.739568 \\
\hline
\end{tabular}

equation is -0.001387 , the standard error is $(0.00369)$, and the $t$-statistic is -0.37644 . There is no cointegration between variables which means there is no long-run equilibrium relationship between them. VAR model is used for a short-run relationship to give us the lags where the short equilibrium relation had existed. In the following model, two equilibrium relations occurred; the first one is for INV $(-4)$ in the INV equation, the $T$-statistic is -3.22598 , which means that the optimal lag is four where the equilibrium has done. The second equilibrium occurred at lag 1 for IR $(-1)$ in the IR equation. The value of $t$-statistic is -2.28952 , which is above the $t$-statistic of 1.96 . The results of $\mathrm{D}$ (INV) equation show that the coefficients are negatively significant at lag four. The D(IR) equation shows that the coefficient is also negatively significant at lag one.

The var analysis above Table 6 shows that the value of the fourth lag's coefficient is significant for the dependent variable domestic investment; the value of $T$-statistic is the absolute value of -3.22598 in which is more than the $t$ statistic 1.96 . the value of the lending rate's coefficient is significant at the first lag where the $T$-statistic -2.28952 is more than the critical value of the $t$-statistic; this means that they are influenced at this period. The negative sign indicates a negative relationship between domestic investment and the lending rate of the shekel in the short-run supporting theories of Keynes \& neoclassical approach.

The adjusted coefficient of determination $(R$-squared $=0.403543)$ in INV-equation indicates that the explanatory variable of (IR) explains about $40 \%$ of the investment.

\subsection{VAR and Granger causality}

Table 7 table below shows the causality between the dependent variable domestic investment and the independent variable lending rate. The null hypotheses $\mathrm{Y}$ cannot cause $\mathrm{X}$; in the shown model, the first table shows that IR (lag1, lag2, lag3 and lag 4) jointly cannot cause INV because the $p$-value is $61.5 \%$, which is bigger than $5 \%$, so the null hypotheses cannot be rejected, which means that IR cannot cause domestic investment. The second table shows that the $p$-value is $78.5 \%$, which is more than $5 \%$, so the null hypothesis of INV is accepted and cannot cause IR.

In Table 7 VAR Granger causality analysis is used to test whether the dependent variable of domestic investment leads to lending rate or causes it, whether lending rate causes 
domestic investment or not, the results accept the null hypotheses that there is no causality for both variables, neither investment causes IR nor IR causes investment.

\subsection{Autocorrelation test}

The LM test's null hypothesis indicates that there is no serial correlation in the residuals up to the specified order. The $p$-value is $26 \%$, which is more than $5 \%$. That means the null hypothesis is accepted. The model has no serial correlation, which is a good result; there is no delayed copy of the variable and itself as a function of delay; there is a similarity between observations as a function of the time lag between them. However, the results accept the null hypothesis, and there is no serial correlation in this model.

\subsection{Impulse responses}

Figure 1 shows the relation (impulse) between two variables, investment and IR. The impulse of investment to the lending rate shows how the INV reacts to IR when there is a shock given

\begin{tabular}{llrr}
\hline Excluded & Chi-sq & df & Prob \\
\hline Dependent variable: D (INV) & & & 0.6150 \\
D(IR) & 2.666893 & 4 & 0.6150 \\
All & 2.666893 & 4 & VAR Granger \\
& & & Table 7. \\
Dependent variable: D (IR) & 1.729272 & 4 & 0.7854 \\
D(INV) & 1.729272 & 4 & 0.7854 exogeneity Wald tests \\
All & & & \\
\end{tabular}

Response to Cholesky One S.D. Innovations \pm S.E.
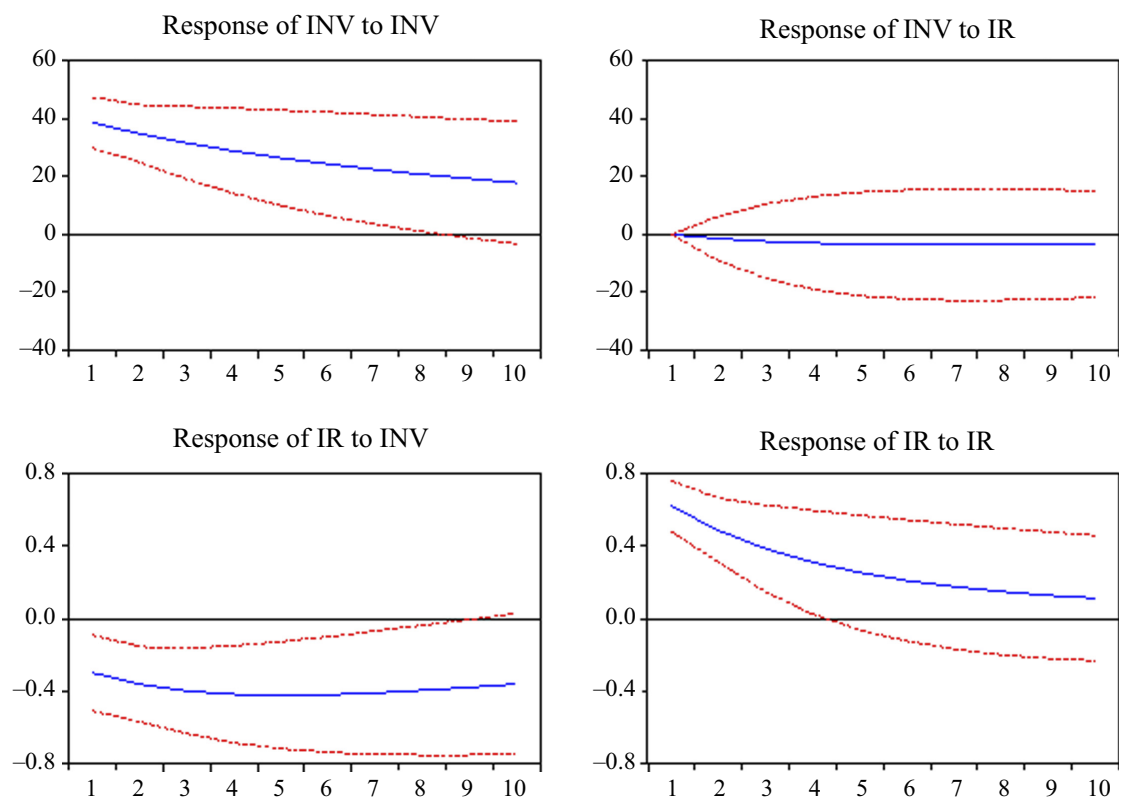

Figure 1.

The relationship (impulse) between investment and interest rate 

$\underset{1,1}{\text { JBSED }}$

82 when standard deviation shock is given to IR in the residual and then the inv's reaction. In other words, when the IR has a positive shock, the investment becomes negative when it is located below the $x$-axis as shown in Figure 1 below.

\subsection{Granger and causality test}

The results in Table 9 below confirm that the analysis of VAR and Granger causality reveals that there isn't any causality between the variables so that no one causes the other.

\subsection{VAR, forecast error variance decomposition}

The results in Table 10 below show that in the short-run, in quarter two, impulse or shock scores $93.21 \%$ variation of the fluctuation in the variable INV (own shock), meaning that the shock in the INV can cause a $93.21 \%$ variation of the fluctuation in the variable INV. It also means that the variable IR does not have any substantial influence in INV; in that case, this variable has a robust exogenous impact on the variable INV. In other words, the domestic investment has a strong influence on itself, but the lending rate has a weak influence on it in both the short and long runs. In the long term, the impact on the tenth quarter is $90.26 \%$ of itself, whereas the lending rate has a $9.74 \%$ influence on domestic investment. In other words, the model has a solid endogenous (implies strong influences from its own) and strong exogenous (implies weak influence from a dependent variable). In the short-run (period 1), D $(\mathrm{INV})=100$ and $\mathrm{D}(\mathrm{IR})=0.00$; first quarter the endogenous variable shows no influence of $\mathrm{IR}$, at the 12 periods (fourth quarter of the third year still has a weak influence by the exogenous variable, this means that in both short and long runs, the endogenous has a strong influence by itself). The model has strong exogenous as well because the dependent variable (INV) has a weak influence on it; in the first lag (quarter one), the endogenous effects exogenous by $12.65617 \%$, which is considered weak; whereas in the long run, lag 12 (fourth quarter of year three) the endogenous variable affects the exogenous by $12.43055 \%$ which is also vulnerable, meaning that the model has a robust exogenous variable.

\section{Conclusions, policy implications and further research}

This study examines the effect of two determinants of the domestic private investment in Palestine using domestic private investment as a dependent variable, while IR, POLINS and GDP as explanatory variables between 2008 and 2017. The study confirms the neoclassical approach in Palestine according to the impact of the IR on domestic investment. In contrast, the POLINS associated with Gaza's war has a positive effect on domestic investment. Such support recent public opinion polling in the USA shows a significant number of people who believe that war and military spending have improved the economy. This contradicts the widespread public acknowledgment and understanding of the human cost of war. In other

\begin{tabular}{lcc}
\hline Lags & LM-stat & Prob \\
\hline 1 & 5.284348 & 0.2593 \\
Note(s): Probs from chi-square with 4 df & & \\
\hline
\end{tabular}

Table 8.

VAR residual serial correlation LM tests

\begin{tabular}{lccc}
\hline Null hypothesis & Obs & F-statistic & Prob \\
\hline IR does not Granger cause INV & 39 & 0.12915 & 0.7214 \\
INV does not Granger cause IR & & 2.59288 & 0.1161 \\
\hline
\end{tabular}

Table 9.

Granger causality test 


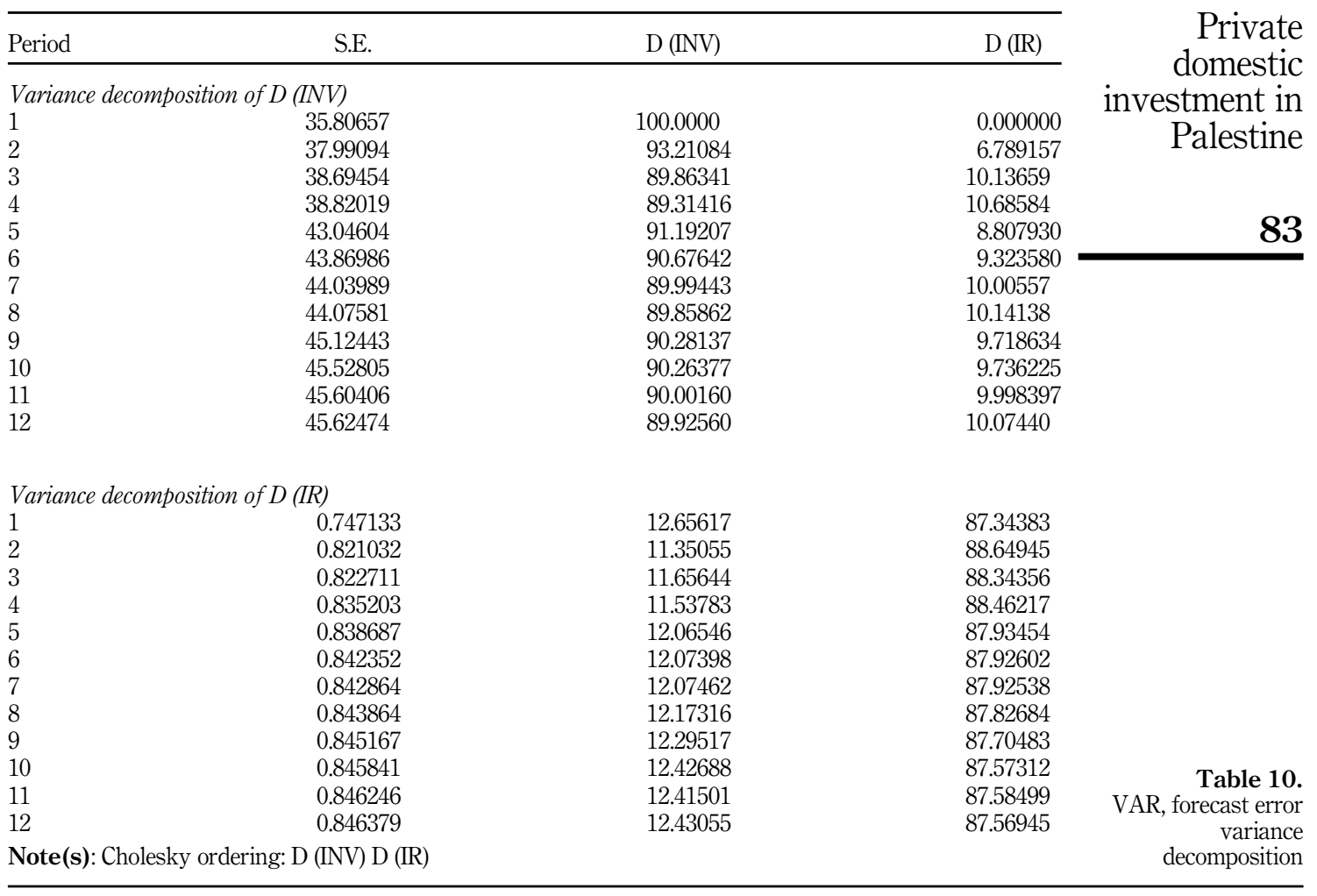

words, some countries that produce weapons may benefit due to conflicts, but this cannot be considered as a good indicator of domestic private investment improvement. In contrast, Palestine has a unique situation because domestic private investment mainly depends on the spending of individuals, companies, government and donor countries on reconstruction.

The study uses sophisticated techniques based on time series analyses such as ARDL \& bound test, VAR tests, causality and forecast error and decomposition and impulse response. These tests reveal that there is no integration between the study variables in the long-run. Moreover, there is no causality between domestic investment and lending rate. It also employed the ADF-test to avoid unit root problems that are usually related to time-series data. On the other hand, the national currency is still not found in Palestine. Policies are recommended to draw an appropriate ratio of the IR for the currencies-in-circulation for boosting investment and economic development.

Based on the study results and conclusions, the researcher comes up with several policy implications. Paying more attention to establishing fundraising parts to support domestic investment funded by local investors and government, in addition to supporting local and Palestinian investors to stimulate investment for improved economic development, this policy can be applied in the short run.

A cost-benefit analysis concerning establishing a Palestinian national currency should be taken into account by policymakers. Such a long-run policy is likely to allow decision-makers to draw a reasonable IR that may reduce it to zero levels or a superficial level for stimulating domestic private investment. In particular, lower IRs encourage additional investment spending, giving the Palestinian economy a boost in slow economic growth. 
JBSED

1,1

\section{4}

The Palestinian National Authority is advised to adopt a policy of tackling the rate of consumption level. This policy can play an essential role in encouraging the demand for investment in small and medium enterprises and, therefore, GDP growth. Such an expansionary policy will encourage private sectors of industry and agriculture.

Finally, achieving self-reliance instead of being a dependent economy is necessary to make use of the policy implications stated above.

\subsection{Further research}

This study was highlighted several research gaps on which further research would be beneficial to the Palestinian economy's policymakers. Further research topics may focus on the following:

(1) The impact of foreign aids and government spending on aggregate demand. Empirical evidence from Palestine.

(2) The relationship between the Palestinian trade deficit and fluctuations of the circulated currencies in Palestine: Time series analysis.

(3) The impact of COVID-19 pandemic on private domestic investment: Empirical evidence from Palestine.

\section{Declarations:}

This is to confirm that,

(1) Data and materials used in this study are available with authors and upon your request.

(2) The authors declare that they have no funding for this research.

(3) The content of this paper has not been published or submitted for publication elsewhere. In addition, the three co-authors made a significant contribution and are in agreement with the contents of this paper.

\section{References}

Abadi, M. and Husain, R. (2013), "The impact of macroeconomic on domestic private investment in Algeria (1989-2009)", Studies of Administrative Sciences, Vol. 40 No. 2, pp. 430-441, doi: 10. $12816 / 0002642$.

Abdel Kader, H. (2015), "Political, instability, uncertainty, democracy, and economic growth in Egypt", Economic Research Forum Working Paper, Vol. 953, pp. 2-18.

Aftab, N., Jebran, K. and UIIAH, I. (2016), "Impact of interest rate on private sector credit. Evidence from Pakistan”, Jinnah Business Review, Vol. 4 No. 1, pp. 47-52.

Agrawal, P. (2004), "Interest rates and investment in East Asia: an empirical evaluation of various financial liberalization hypothesis", The Journal of Development Studies, Vol. 40 No. 3, pp. 142-173.

Anthony, D. and Joe, O. (2015), "Determinants of investment in the Nigerian economy: an empirical approach (1990-2013)", International Journal of Financial Research, Vol. 6 No. 4, pp. 217-227.

Athukorala, P. (2007), "Interest rates, saving and investment: evidence from India", Oxford Development Studies, Vol. 26 No. 2, pp. 153-169, doi: 10.10/13600819808424151.

Awad, I.M. and Alazzeh, W. (2020), "Using currency demand to estimate the Palestine underground economy: an econometric analysis", Palgrave Commun, Vol. 6, p. 56, doi: 10.1057/s41599-0200433-4.

Awad, I. and Karaki, M. (2019), "The impact of bank lending on palestine economic growth: an economic analysis of time series data", Financial Innovation, Vol. 5, pp. 1-19, doi: 10.1186/540854a_019_ 0130_8. 
D bour, N. (1998), "Prospect for and problems of the Palestinian economy in the west bank and Gaza Strip", Journal of Economic Cooperation among Islamic Countries, Vol. 19 No. 3 (1998), pp. 1-53.

Engle, R. and Granger, C. (1987), "Co-integration and error correction: representation, estimation, and testing”, Econometrica, Vol. 55 No. 2, pp. 251-276, doi: 10.2307/1913236.

Etim, E., Abang, M. and Ekpenyong, I. (2018), "Interest rate and domestic private investment in Nigeria", International Journal of Research and Innovation in Social Science (IJRISS), Vol. 2 No. 10, pp. 198-206, ISSN: 2454_6186.

Granger, C.W.J. (1969), "Investigating causal relations by econometric models and cross-spectral methods", Econometrica, Vol. 37 No. 3, pp. 424-438.

Gujarati, D. (2020), Advanced Econometrics, 5th ed., Solutions, Boston.

Hansen, A.H. (1951), "Classical, loanable fund, and Keynesian interest theories”, Quarterly Journal of Economics, Vol. 65, pp. 429-432.

Jelilov, G. (2016), "The impact of interest rate on economic growth example of Nigeria", African Journal of Social Science, Vol. 6 No. 2, pp. 51-64.

MacKinnon, J.G., Haug, A.A. and Michelis, L. (1999), "Numerical distribution functions of likelihood ratio tests for cointegration", Journal of Applied Econometrics, Vol. 14, pp. 563-577.

Masih, M. and Nazeer, A. (2017), "Impact of political instability on foreign direct investment and economic growth: evidence from Malaysia”, pp. 1-19, available at: http://mpra.ub.uni-muenchen. de/79418/.

Mbaye, E. (2012), Determinants of Domestic Private Investments in Kenya, University of Nairobi, Nairobi, pp. 1-40, X50/76251/2012.

Mushtaq, S. and Siddiqui, D. (2016), "Effect of interest rate on economic performance: evidence from Islamic and non- Islamic economics", Financ Innov, Vol. 2 No. 9, pp. 2-14.

Najaf, K. and Najaf, R. (2016), "Impact of political stability on macroeconomic variables and FDI of Pakistan”, Developing Country Studies, Vol. 6 No. 2, pp. 109-115, ISSN2224_607X(paper/ ISSN2225_0565(online).

Nelson, T. (2018), "Effect of lending interest rate on domestic private investment in Kenya", International Journal of Social Science and Economic Research, Vol. 3 No. 2, pp. 681-689, ISSN: 2455_8834.

Ohlin, B. (1937), "Some Notes on the Stockholm theory of savings and investment 2", The Economic Journal, Vol. 47, pp. 221-240.

Ojima, D. and Fabian, E. (2015), "Impact of interest rate on investment in Nigeria", Developing Country Studies, Vol. 5 No. 3, pp. 103-109, ISSN:2224_607X (paper) ISSN:2225_0565(online).

Palestinian Central Burea of Statistics (PCBS) (2017), available at: http://www.pcbs.gov.ps/site/lang_ en/1/default.aspx.

Palestine Monetary Authority (PMA), P.M (2012), Statistics Time Series Data, available at: http://www. pma.ps/.

Pesaran, M.H., Shin, Y. and Smith, R.J. (2001), "Bound testing approaches to the analysis of level relationship”, Journal of Applied Economics, Vol. 16, pp. 289-326.

Qahtani, K. (2015), The Impact of Interest Rate on Saudi Economic, Association of Critic Saudi Arabia, Riyadh.

Radu, M. (2015), "The Impact of political determinants on economic growth in CEE Countries", Procedia_Social and Behavioral Science, Vol. 197 No. 25, pp. 1990-1996, doi: 10.1016/j.sbs.

Robertson, D.H. (1934), "Industrial fluctuation and the natural rate of interest", The Economic Journal, Vol. 44, pp. 650-656.

Sims, C. (1980), "Macroeconomics and reality", Econometrica, Vol. 48 No. 1, pp. 1-48.

\section{Private domestic investment in \\ Palestine}


JBSED 1,1

Stiglitz, J. (1968), Theory of Liquidity Preference and the Term Structure of Interest Rates, Yale University, pp. 1-43, available at: http://cowles.yale.edu/sites/default/files/files/pub/d02/ d0252.pdf.

Stiglitz, J. (1987), "The causes and consequences of the dependence of quality on Price", Journal of Economic Literature, Vol. XXV Nos 1-48, available at: http://www.jstor.org/stable/2726189.

Thirlwall, A. and Warman, F. (2007), "Interest rates, saving investment and growth in Mexico 196090: tests of the financial liberalization hypothesis", The Journal of Development Studies, Vol. 30 No. 3, pp. 629-649, doi: 10.1080/00220389408422330.

Wooldridge, J. (2020), Introductory Economics, A Modern Approach, 7th ed., Boston.

\section{Further reading}

Ali, M., Zaman, T. and Bin Amir, Z. (2012), "The macroeconomic determinant of investment: empirical evidence from Bangladesh", International Journal of Scientific Engineering and Research, Vol. 3 No. 9, pp. 460-472.

Anokwuru, C. (2017), "Interest rate and domestic private investment in Nigeria", IIARD International Journal of Economics and Business Management, Vol. 3 No. 5, pp. 43-49.

Arnon, A. and Bamya, S. (2015), Economics and Politics in the Israeli Palestinian Conflict, The AIX Group, Jerusalem.

Eklund, J. (2013), "Theories of investment: a theoretical review with empirical applications", Swedish Entrepreneurship Forum, pp. 1-12, available at: https://entreprenorskapsforum.se/wp-content/ uploads/2013/03/WP_22.pdf.

Fielding, D. (2002), "Human rights, political instability and investment in South Africa, a note", Journal of Development Economics, Vol. 67, pp. 173-18, available at: www.elsevier.com/locate/econbase.

Malawi, I. and Backer, M. (2010), "The impact of interest rate on investment in Jordan: a cointegration analysis", JKAU ad Adm, Vol. 24 No. 1, pp. 199-209, doi: 10.4197/Eco.24-1.6.

Ohlin, B., Robertson, D.H. and Hawtrey, R.G. (1937), "Alternative theories of the rate of interest: three rejoinders", The Economic Journal, Vol. 47, p. 424.

Investopedia: $\mathrm{https} / /$ www.investopedia.com/terms/k/keynesianeconomics.asp

\section{Corresponding author}

Ibrahim M. Awad can be contacted at: iawad@staff.alquds.edu

For instructions on how to order reprints of this article, please visit our website:

www.emeraldgrouppublishing.com/licensing/reprints.htm

Or contact us for further details: permissions@emeraldinsight.com 